\title{
DETERMINATION OF BOTANICAL COMPOSITION, HAY YIELD AND FORAGE QUALITY OF SOME NATURAL RANGELANDS IN KYRGYZSTAN'S CHUY REGION
}

\author{
CinAR, S. $.^{1,2^{*}}-$ AbDUllayeV, A. ${ }^{1}-$ EsenOV, $N .{ }^{1}-$ KARADAG, Y.${ }^{3}$ \\ ${ }^{I}$ Department of Horticulture and Field Crops, Faculty of Agriculture, Kyrgyz-Turkish Manas \\ University, Bishkek, Kyrgyzstan \\ ${ }_{2}^{2}$ Department of Plant and Animal Production, Technical Vocational School, Kilis 7 Aralik \\ University, Kilis, Turkey \\ ${ }^{3}$ Faculty of Applied Sciences, Mus Alparslan University, Mus, Turkey \\ ${ }^{*}$ Corresponding author \\ e-mail:scinar01@hotmail.com ; selahattin.cinar@manas.edu.kg \\ (Received $4^{\text {th }}$ Sep 2019; accepted $4^{\text {th }}$ Dec 2019)
}

\begin{abstract}
This research was carried out in 2018 in order to determine the hay yields, forage qualities botanical compositions and range conditions of 5 different natural rangelands located at different altitudes the Chuy Region, Kyrgyzstan. In the rangelands, the ratio of plant coverage was 96.0-98.0\%, the ratio of grasses, legumes, other plant families in the plant covered area was $24.5-48.1 \%, 4.7-24.0 \%, 36.2-63.8 \%$, respectively. In the rangelands, the rate of decreaser, increaser and invader species was $37.0 \%, 7.3 \%$ and $55.7 \%$, respectively. The average dry matter yield (DMY) of all five ranges was $2904.6 \mathrm{~kg} \mathrm{ha}^{-1}$, crude protein (CP) was $10.6 \%$, acid detergent fiber (ADF) and neutral detergent fiber (NDF) compositions were $39.1 \%, 57.1 \%$, respectively. The crude protein yield (CPY) was $307.8 \mathrm{~kg} \mathrm{ha}^{-1}$, digestible dry matter yield (DDMY) was $1699.1 \mathrm{~kg} \mathrm{ha}^{-1}$, and relative feed value (RFV) was 95.3. The rangeland yield increased with altitude. One of the rangelands was in the moderate condition and the others were in poor range condition. According to research results, extensive research targeting appropriate range improvement strategies for each individual rangeland with unique soil and topographic conditions is recommended in order to select among the top seeding, seeding or natural seeding, weed control, grazing methods alone or combined with other range improvement strategies.
\end{abstract}

Keywords: Central Asia, range, yield, quality, range condition

\section{Introduction}

Rangelands are one of the cheapest sources of roughage for animals. In addition to providing the basis for sustainable animal production, rangelands form a functional environment by maintaining the soil.

Plant communities in rangelands are formed as a result of lengthy processes with the combined effects of soil, topography, and climatic factors. Therefore, the vegetation of each rangeland is unique. All plant communities, regardless of their location, evolve over time due to changes in environmental conditions. This process is called plant succession and the change may be in the number of species that make up the vegetation, the ratio of each species in the botanical composition or the rate of vegetation covering the soil. The direction of this change could either be in a more desirable and productive direction or in an undesirable and less productive direction (Blanchet et al., 2003). Plant communities, like other living communities, are in a continuous dynamism.

The rangelands in the Central Asian countries such as Kyrgyzstan, Kazakhstan, Tajikistan, Turkmenistan, and Uzbekistan are the land where the world's largest nomadic 
stockbreeding is carried out. Rangelands account for $65 \%$ of the total surface area of these 5 Central Asian countries. These rangelands are the most important feed source for people with low income nomadic livestock (Blench and Sommer, 1999).

Kyrgyzstan is a mountainous country and people live on agriculture and animal husbandry. $86 \%$ of the total agricultural area consists of mountain rangelands and animal husbandry is based on rangelands. About 6.8 million hectares of Kyrgyzstan rangelands were reported to be in the process of deterioration, 3.0 million hectares have been under the weed occupation, and 1.7 million hectares has been reported to be degraded by overgrazing (Nishanov, 2015). Large degradation in Kyrgyzstan rangelands in the past 25 years due to overgrazing, inadequate research on this subject, the need for determination of conditions of the rangelands, and the need for developing sustainable improvement strategies of rangelands were expressed. According to the results of research carried out in the rangelands in different regions of Narin, presence of a number of taxa including Artemisia dracunculus, Lappula sp., Galium verum, Dracocephalum integrifolium, Ranunculus sp., Onopordum acanthium, Draba nemorosa were reported (Eddy, 2016). Rosales and Livinets (2017) stated that the rangelands were over-grazed by nomads in Kyrgyzstan during the independence period, grass yield and quality in rangelands is reduced, there is a serious lack of management in rangelands, there is not enough statistical information about the degradation of rangelands, overgrazing causes degradation in rangelands, the degradation of rangelands should be determined and improved, and there is lack of enough statistical information about the state of rangelands.

About 9.3 million hectares of the Kyrgyzstan territory is composed of grass prairies and due to the mismanagement of the rangelands, vegetation, yield potential and quality have decreased. This situation adversely affects the livestock and economy of the country and causes the destruction of land and water resources (Mirzabaev et al., 2016). In order to solve these problems, rangelands which have a decreased yield and quality should be rehabilitated, and high-quality feed producing potential should be reinstated. However, in order to be successful in rangeland improvement, the knowledge of the vegetation structure of the rangeland is a prerequisite. Rangeland research conducted in different parts of Turkey revealed that the area covered with plants in rangelands vary greatly. Plant cover percentages of the rangelands s were reported as $53.0 \%-66.0 \%$ by Erkun (1971), as $34.0 \%$ by Erkun (1972), as $14.0-37.0 \%$ by Ozmen (1977), as $17.0 \%$ by Gokkus (1984), as $78.5 \%$ by Cinar (2001), as $82.0 \%$ by Uslu (2005), as $71.9 \%-95.0 \%$ by Sen (2010), as $68.9-95.9 \%$ by Inal et al. (2011), as $84.4-99.0 \%$ by Cinar et al. (2014), as $83.3 \%$ by Ispirli et al. (2016), as $93.6 \%$ by Uzun et al. (2016). A great majority of the plants that are present and produce biomass of rangelands could not benefit animals as they are thorny species and weeds (Cinar et al., 2015).

This research was carried out to investigate the vegetation characteristics of natural rangelands in 5 different altitudes in the Chuy region, where 1/10 of Kyrgyzstan's rangelands is located, and to obtain information that can be used as a basis for improving rangelands in similar eco-geographic regions.

\section{Materials and Methods}

\section{Materials}

The vegetation studies were carried out between 1 June - 8 August 2018 in Tokbay $\left(42^{\circ} 47^{\prime} \mathrm{N}, 7^{\circ} 25^{\prime} \mathrm{E}\right.$, elevation $810-945 \mathrm{~m}$.), Kaskasu (42 $40^{\circ} \mathrm{N}, 74^{\circ} 31^{\prime} \mathrm{E}$, elevation

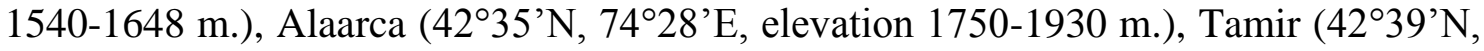


74³9'E, elevation 1910-1950 m) and Chungurchak $\left(42^{\circ} 38^{\prime} \mathrm{N}\right.$, $74^{\circ} 36^{\prime} \mathrm{E}$, elevation 2090-2210 m) rangelands in different altitudes in Kyrgyzstan's Chuy region (Figure 1, Figure 2).

Table 1 shows the aspect, slope, distance to settlement, altitude and grazing intensity values of the rangelands whose vegetation were studied.

The closest meteorological station to the rangeland areas where the survey was conducted was in Bishkek. In Bishkek, total rainfall is $427 \mathrm{~mm}$, average temperature is $10.4^{\circ} \mathrm{C}$ and the highest temperatures are recorded in July and the lowest temperatures are documented in January (Anonymous, 2019).

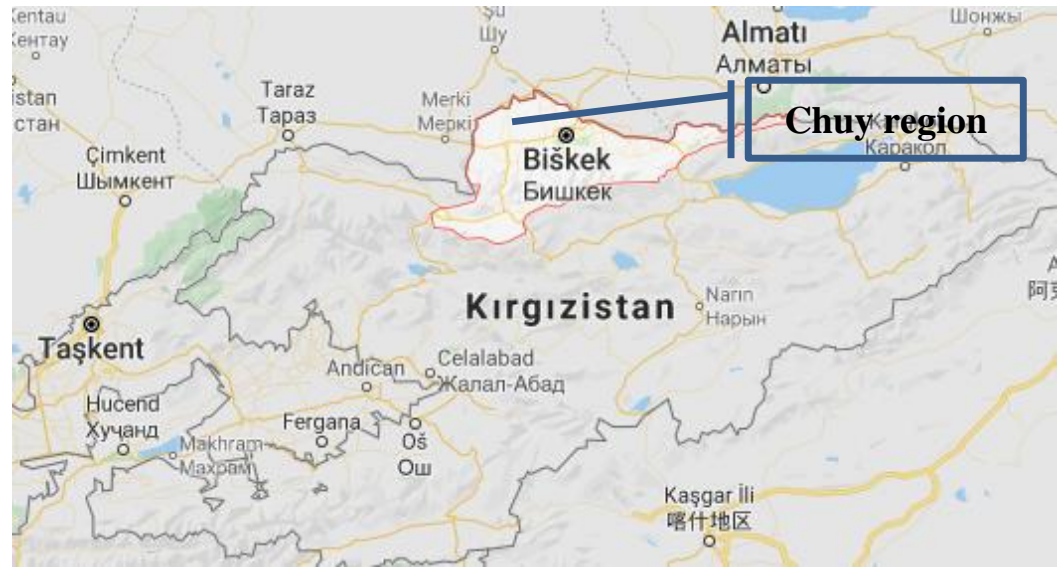

Figure 1. The map of study area

\section{Methods}

A modified wheel point method with loop for the vegetation survey was applied (Anonymous, 1962; Koc and Cakal, 2004) (Figure 2). Loop measurements were carried out in 3 different sections (in blocks) which were very homogeneous in terms of vegetation and soil in each range. The measurements were taken from four lines of $20 \mathrm{~m}$ extending in 4 directions in each block from a point considered as central. A total of 1200 loops were measured in each range, 100 in each $20 \mathrm{~m}$ line and 400 in each block. The ratio of plant covered area $(\%)$, botanical composition based on the percentage in the plant covered area (\%) of the rangelands examined were determined according to the methods described by Gokkus et al. (2000).

Decreaser, increaser, and invader species expressing the responses of plant species to grazing were determined according to Anonymous (2008).

The quality scores of the species found in the rangelands were determined according to Bakır (1987) and degree of quality for each rangeland was estimated with the help of the following equation by Gokkus et al. (2000) (Eq.l) where the ratio of plant species in the botanical composition according to the coverage area and quality scores were used.

$$
\text { PQD: }(\Sigma \mathrm{RxKP}) / 100
$$

where:

PQD: Range quality degree,

$\mathrm{R}$ : The rate of the species in the botanical composition, QS: Quality score of the species. 


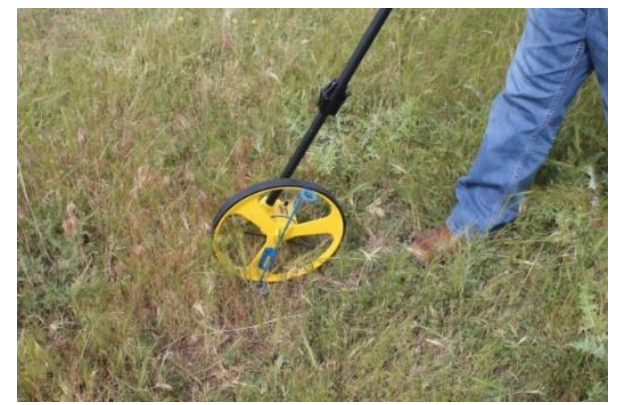

Point wheel method

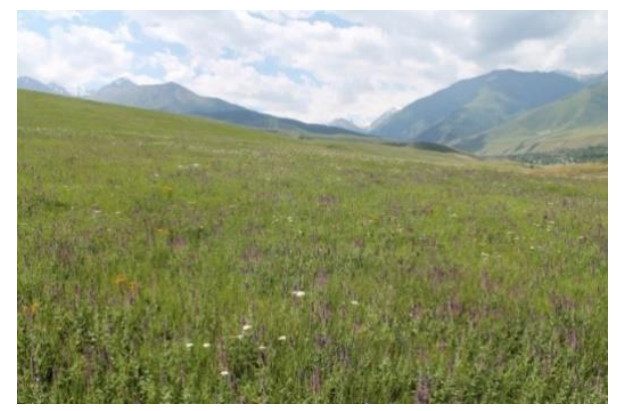

Kaskasu's rangeland

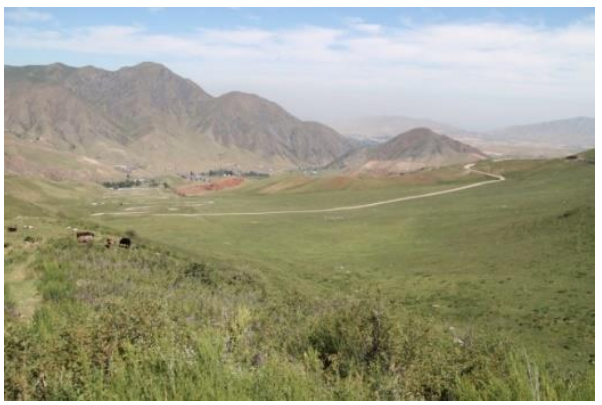

Tamir's rangeland

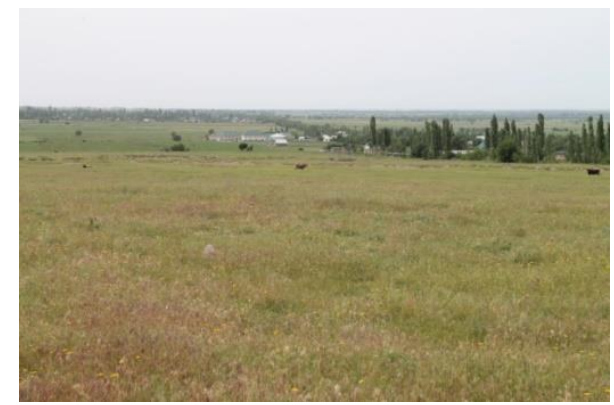

Tokbay's rangeland

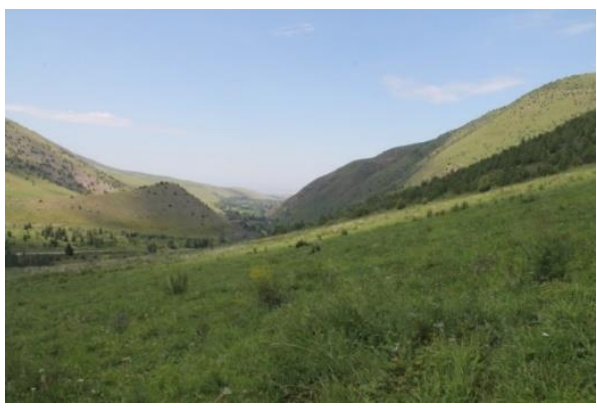

Alaarca's rangeland

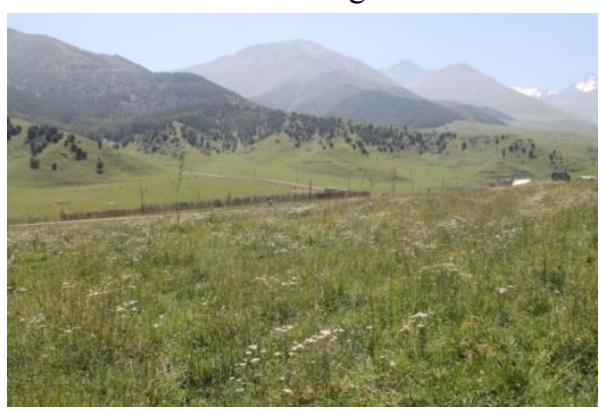

Chungurchak's rangeland

Figure 2. Point wheel method used in vegetation study and vegetation surveyed rangeland

Table 1. Aspect, altitude, slope, area, longitude and latitude values for the rangelands whose vegetation were studied

\begin{tabular}{c|c|c|c|c|c}
\hline Range & Aspect & Slope $\left(^{\circ}\right)$ & $\begin{array}{c}\text { Distance to } \\
\text { Settlement }(\mathbf{k m})\end{array}$ & Altitude (m.) & $\begin{array}{c}\text { Grazing } \\
\text { Intensity }\end{array}$ \\
\hline Tokbay & Base & $0-5$ & $0-1$ & $810-945$ & Heavy \\
Kaskasu & West & $5-15$ & $0-1$ & $1540-1648$ & Moderate \\
Alaarca & South-North & $30-40$ & $10-15$ & $1750-1930$ & Light \\
Tatır & West & $15-25$ & 3 & $1910-1950$ & Moderate \\
Chungurchak & East-West & $0-30$ & 10 & $2090-2210$ & Moderate \\
\hline
\end{tabular}

Plant identification in vegetation studies were conducted according to Edgecombe (1964), Garms et al. (1968), Davis (1970), Polunin and Huxley (1974), Huxley and Taylor (1977), Weymer (1981), Demiri (1983), Oztan and Okatan (1985) and Anonymous (2005, 2008, 2015). Life spans, families, and respons to grazing were determined according to Anonymous (2008, 2019).

The vegetation in the $70 \times 70 \mathrm{~cm}$ dimension quadrats from the 5 th, 10 th, 15 th $\mathrm{m}$ of each loop of the three plots were cut with scissors from soil level. The plant species that were 
harvested from each quadrat were divided into groups as grasses, legumes and other plant families. Plant samples of each group were dried for 24 hours in a drier at $65^{\circ} \mathrm{C}$ until the samples reach a constant weight. Then, each of the three plant groups were separately weighed and the sum of the dry weights was recorded as dry matter yield. After the average of dry matter yield values were determined for 12 quadrats taken from each plot and were converted to dry matter yield per hectare.

After drying and weighing the plant samples, nitrogen content was determined by Kjeldahl method by combining the samples belonging to 12 quadrats of each group. The determined nitrogen content was multiplied by 6.25 conversion coefficient and crude protein \% values were estimated in each plant sample of the plant groups (Anonymous, 1995). The average crude protein contents of the plant specimens were determined by summing the figures obtained by increaser the ratios of the plant groups in the botanical composition in each plot by the crude protein ratio values.

NDF and ADF contents of the dried hay samples were analyzed using ANKOM 220 Fiber Analyzer and according to the methods described by Ankom (2009). In the calculation of $\mathrm{CP}, \mathrm{ADF}$ and NDF contents of plant samples in each plot, the ratios of plant groups in botanical composition based on the weight in each plot were multiplied with the CP, ADF and NDF and the sum of the obtained values were recorded as CP, $\mathrm{ADF}$ and NDF ratio of plant samples from the plot.

CPY, DDMY, dry matter intake (DMI), digestible dry matter (DDM) and RFV were estimated according to the following equations (Eq.2, Eq.3, Eq.4) adapted from Sheaffer et al. (1995):

$$
\begin{gathered}
\mathrm{DMI}=120 /(\mathrm{NDF} \%) \text { dry matter basis } \\
\mathrm{DDM}=88.9-(0.779 \times \mathrm{ADF} \% \text { dry matter basis }) \\
\mathrm{RFV}=(\mathrm{DDM} \% \times \mathrm{DMI}) / 1.29 \\
\mathrm{CPY}=\mathrm{CP} \% \times \mathrm{DMY}
\end{gathered}
$$

\section{Statistical Analyses}

Considering the data gathered in a randomized complete block design, ANOVA analyses were performed for plant-covered area, botanical composition, DMY, CP, ADF, NDF, CPY, DDMY, RFV variables using MSTAT-C statistical package program (Steel and Torrie, 1960). Angle transformation was applied to data on the plant cover percentage and percentages of plant groups in the botanical composition before conducting analyses of variance (Tekindal, 1998). Duncan multiple comparison test was used for mean separations (Yurtsever, 1984).

\section{Results and Discussion}

\section{Botanical Composition}

The species, their families, life spans, types of response to grazing, coverage rates, percentages in botanical composition and some other vegetation characteristics of the five natural rangelands examined in the research are given in Table 2 and Table 3. 
Table 2. Life spans, families, response to grazing and plant coverage rates, botanical composition of the species determined in the investigated rangelands

\begin{tabular}{|c|c|c|c|c|c|}
\hline \multicolumn{6}{|c|}{ Tokbay } \\
\hline Family & Species & Life Span & $\begin{array}{c}\text { Response to } \\
\text { Grazing }\end{array}$ & $\begin{array}{c}\text { Plant Coverage } \\
\text { Rates }(\%)\end{array}$ & $\begin{array}{c}\text { Percentage in } \\
\text { Botanical } \\
\text { Composition }(\%)\end{array}$ \\
\hline Poaceae & Bromus tomentellus & Perennial & Decreaser & 13.7 & 14.1 \\
\hline Poaceae & Bromus japonicus & Annual & Invader & 13.7 & 14.1 \\
\hline Poaceae & Cynodon dactylon & Perennial & Increaser & 1.0 & 1.0 \\
\hline Poaceae & Hordeum bulbosum & Perennial & Decreaser & 0.3 & 0.3 \\
\hline Poaceae & Nardus stricta & Perennial & Invader & 1.3 & 1.4 \\
\hline Poaceae & Poa апnиа & Annual & Invader & 1.0 & 1.0 \\
\hline Poaceae & T. caput medusa & Annual & Invader & 9.0 & 9.3 \\
\hline Fabaceae & Alhagi pseudalhagi & Perennial & Invader & 0.7 & 0.7 \\
\hline Fabaceae & Medicago minima & Annual & Invader & 20.3 & 20.9 \\
\hline Fabaceae & Vicia tenufolia & Perennial & Decreaser & 0.3 & 0.3 \\
\hline Asteraceae & Achillea filipendula & Perennial & Invader & 2.3 & 2.4 \\
\hline Asteraceae & Achillea wilhelmsi & Perennial & Invader & 7.3 & 7.6 \\
\hline Asteraceae & Artemisia caucasica & Perennial & Invader & 10.3 & 10.7 \\
\hline Asteraceae & Cichorium inytbus & Perennial & Invader & 0.7 & 0.7 \\
\hline Asteracae & Picnomon acarna & Annual & Invader & 1.3 & 1.4 \\
\hline Asteraceae & Gundelia tournofertii & Perennial & Invader & 9.0 & 9.3 \\
\hline Brassicaceae & C.bursa pastoris & Annual & Invader & 0.5 & 0.3 \\
\hline Brassicaceae & Lepidium perfoliatum & Annual & Invader & 0.7 & 0.7 \\
\hline Geraniaceae & Geranium cicutarium & Perennial & Invader & 0.3 & 0.3 \\
\hline Papaveraceae & Papaver orientale & Perennial & Invader & 0.3 & 0.3 \\
\hline Primulaceae & Anagallis arvensis & Annual & Invader & 0.7 & 0.7 \\
\hline Rosaceae & Potentilla bifurca & Perennial & Invader & 1.0 & 1.0 \\
\hline Rubiaceae & Galium aparine & Annual & Invader & 1.0 & 1.0 \\
\hline Scrophulariaceae & e Verbascum songoricum & Perennial & Invader & 0.3 & 0.3 \\
\hline Total & & & & 97.0 & 100.0 \\
\hline \multicolumn{6}{|c|}{ Kaskasu } \\
\hline Family & Species & Life Span & $\begin{array}{l}\text { Response to } \\
\text { Grazing }\end{array}$ & $\begin{array}{c}\text { Plant } \\
\text { Coverage } \\
\text { Rates }(\%)\end{array}$ & $\begin{array}{c}\text { Percentage in } \\
\text { Botanical } \\
\text { Composition }(\%)\end{array}$ \\
\hline Poaceae & Dactylis glomerata & Perennial & Decreaser & 0.3 & 0.3 \\
\hline Poaceae & Festuca ovina & Perennial & Increaser & 11.0 & 11.5 \\
\hline Poaceae & Lolium perenne & Perennial & Decreaser & 15.7 & 16.2 \\
\hline Poaceae & Stipa lessingiana & Perennial & Increaser & 2.3 & 2.5 \\
\hline Fabaceae & Medicago falcata & Perennial & Decreaser & 7.3 & 7.7 \\
\hline Fabaceae & Onobrychis arenaria & Perennial & Decreaser & 6.7 & 7.0 \\
\hline Fabaceae & Trifolium pratense & Perennial & Decreaser & 6.0 & 6.2 \\
\hline Fabaceae & Trifolium repens & Perennial & Decreaser & 3.0 & 3.1 \\
\hline Asteraceae & Achillea millefolium & Perennial & Invader & 9.0 & 9.4 \\
\hline Asteraceae & Artemisia dracunculus & Perennial & Invader & 0.3 & 0.4 \\
\hline Asteraceae & Conyza canadiensis & Annual & Invader & 0.3 & 0.3 \\
\hline Asteraceae & Inula oculus-christi & Perennial & Invader & 0.3 & 0.3 \\
\hline Asteraceae & Taraxacum officinalis & Perennial & Invader & 0.3 & 0.3 \\
\hline Convolvulaceae & Convolvulus arvensis & Perennial & Invader & 2.0 & 2.1 \\
\hline Hyperiaceae & Hypericum perforatum & Perennial & Invader & 3.3 & 3.5 \\
\hline Lamiaceae & Origanum vulgare & Perennial & Invader & 3.0 & 3.1 \\
\hline Lamiaceae & Phlomoides oreophila & Perennial & Invader & 1.0 & 1.1 \\
\hline Lamiaceae & Salvia verticillata & Perennial & Invader & 12.3 & 12.8 \\
\hline Plantaginaceae & Plantago lanceolata & Perennial & Increaser & 1.7 & 1.7 \\
\hline Rosaceae & Potentilla recta & Perennial & Invader & 9.0 & 9.4 \\
\hline Rubiaceae & Galium verum & Perennial & Invader & 1.0 & 1.0 \\
\hline Total & & & & 96.0 & 100 \\
\hline
\end{tabular}




\begin{tabular}{|c|c|c|c|c|c|}
\hline \multicolumn{6}{|c|}{ Alaarca } \\
\hline Family & Species & Life Span & $\begin{array}{l}\text { Response to } \\
\text { Grazing }\end{array}$ & $\begin{array}{c}\text { Plant } \\
\text { Coverage } \\
\text { Rates }(\%) \\
\end{array}$ & $\begin{array}{c}\text { Percentage in } \\
\text { Botanical } \\
\text { Composition }(\%) \\
\end{array}$ \\
\hline Poaceae & Dactylis glomerata & Perennial & Decreaser & 16.7 & 17.3 \\
\hline Poaceae & Lolium rigidum & Annual & Invader & 3.3 & 3.4 \\
\hline Poaceae & Poa bulbosa & Perennial & Decreaser & 3.7 & 3.8 \\
\hline Fabaceae & Trifolium pratense & Perennial & Decreaser & 4.0 & 4.1 \\
\hline Fabaceae & Trifolium repens & Perennial & Decreaser & 7.3 & 7.6 \\
\hline Asteraceae & Achillea millefolium & Perennial & Invader & 7.7 & 7.9 \\
\hline Asteraceae & Achillea wilhelmsi & Perennial & Invader & 5.3 & 5.5 \\
\hline Asteraceae & Taraxacum officinalis & Perennial & Invader & 7.3 & 7.6 \\
\hline Geraniaceae & Geranium molle & Annual & Invader & 9.0 & 9.3 \\
\hline Hyperiaceae & Hypericum perforatum & Perennial & Invader & 4.7 & 4.8 \\
\hline Lamiaceae & Mentha longifolia & Perennial & Invader & 3.7 & 3.8 \\
\hline Lamiaceae & Marribum parviflorum & Perennial & Invader & 3.0 & 3.1 \\
\hline Lamiaceae & Teucrium polium & Perennial & Increaser & 2.0 & 2.1 \\
\hline Lilliaceae & Allium schoenoprosum & Perennial & Invader & 2.3 & 2.4 \\
\hline Plantaginaceae & Plantago lanceolata & Perennial & Invader & 4.7 & 4.8 \\
\hline Polygonaceae & Polygonum aviculare & Perennial & Invader & 1.7 & 1.7 \\
\hline Rosaceae & Potentilla recta & Perennial & Invader & 5.7 & 5.9 \\
\hline Rubiaceae & Galium verum & Perennial & Invader & 4.7 & 4.8 \\
\hline Total & & & & 96.7 & 100 \\
\hline \multicolumn{6}{|c|}{ Tamir } \\
\hline Family & Species & Life Span & $\begin{array}{l}\text { Response to } \\
\text { Grazing }\end{array}$ & $\begin{array}{c}\text { Plant } \\
\text { Coverage } \\
\text { Rates (\%) } \\
\end{array}$ & $\begin{array}{c}\text { Percentage in } \\
\text { Botanical } \\
\text { Composition (\%) }\end{array}$ \\
\hline Poaceae & Cynodon dactylon & Perennial & Increaser & 6.0 & 6.1 \\
\hline Poaceae & Dacylis glomerata & Perennial & Decreaser & 23.7 & 24.2 \\
\hline Poaceae & Poa bulbosa & Perennial & Decreaser & 3.0 & 3.1 \\
\hline Fabaceae & Medicago falcata & Perennial & Decreaser & 0.7 & 0.7 \\
\hline Fabaceae & Trifolium pratense & Perennial & Decreaser & 0.7 & 0.7 \\
\hline Fabaceae & Trifolium repens & Perennial & Decreaser & 3.3 & 3.4 \\
\hline Apiaceae & Carum carvi & Perennial & Invader & 4.7 & 4.7 \\
\hline Asteraceae & Achillea millefolium & Perennial & Invader & 10.0 & 10.2 \\
\hline Asteraceae & Artemisia dracunculus & Perennial & Invader & 0.3 & 0.3 \\
\hline Asteraceae & Inula oculus-christi & Perennial & Invader & 0.3 & 0.3 \\
\hline Asteraceae & Taraxacum officinale & Perennial & Invader & 0.7 & 0.7 \\
\hline Boraginaceae & B.incrassata & Annual & Invader & 0.3 & 0.3 \\
\hline Brassicaceae & C.bursa-pastoris & Annual & Invader & 2.0 & 2.0 \\
\hline Caryophyllaceae & Silene vulgaris & Perennial & Invader & 1.0 & 1.0 \\
\hline Geraniaceae & Geranium collinum & Perennial & Invader & 11.0 & 11.3 \\
\hline Hyperiaceae & Hypericum perforatum & Perennial & Invader & 0.7 & 0.7 \\
\hline Lamiaceae & Origanum vulgare & Perennial & Invader & 14.0 & 14.4 \\
\hline Lamiaceae & Phlomis oreophila & Perennial & Invader & 2.7 & 2.7 \\
\hline Lamiaceae & Stachys cretica & Perennial & Invader & 1.3 & 1.4 \\
\hline Polygonaceae & Rumex crispus & Perennial & Invader & 0.3 & 0.3 \\
\hline Ranunculaceae & Aconitum exelsum & Perennial & Invader & 3.3 & 3.4 \\
\hline Ranunculaceae & Ranunculus kotschyi & Perennial & Invader & 1.0 & 1.0 \\
\hline Rosaceae & Potentilla orientalis & Perennial & Invader & 7.0 & 7.1 \\
\hline Total & & & & 97.3 & 100.0 \\
\hline \multicolumn{6}{|c|}{ Chungurchak } \\
\hline Family & Species & Life Span & $\begin{array}{l}\text { Response to } \\
\text { Grazing }\end{array}$ & $\begin{array}{c}\text { Plant } \\
\text { Coverage } \\
\text { Rates (\%) } \\
\end{array}$ & $\begin{array}{c}\text { Percentage in } \\
\text { Botanical } \\
\text { Composition }(\%)\end{array}$ \\
\hline Poaceae & Agropyron intermedium & Perennial & Decreaser & 1.3 & 1.3 \\
\hline Poaceae & Cynodon dactylon & Perennial & Increaser & 10.7 & 11.1 \\
\hline Poaceae & Dacylis glomerata & Perennial & Decreaser & 18.0 & 18.3 \\
\hline Poaceae & Poa bulbosa & Perennial & Decreaser & 17.0 & 17.4 \\
\hline
\end{tabular}




\begin{tabular}{llllcc} 
Fabaceae & Astragalus onobrychis & Perennial & Decreaser & 1.3 & 1.4 \\
Fabaceae & Trifolium repens & Perennial & Decreaser & 12.3 & 12.6 \\
Fabaceae & Trifolium pratense & Perennial & Decreaser & 1.7 & 1.7 \\
Asteraceae & Achillea millefolium & Perennial & Invader & 8.7 & 8.9 \\
Asteraceae & Artemisia dracunculus & Perennial & Invader & 0.3 & 0.3 \\
Asteraceae & Inula oculus -christi & Perennial & Invader & 0.3 & 0.3 \\
Asteraceae & Taraxacum officinale & Perennial & Invader & 7.3 & 7.6 \\
Geraniaceae & Geranium collinum & Perennial & Invader & 13.3 & 13.9 \\
Geraniaceae & Geranium verum & Perennial & Invader & 0.3 & 0.3 \\
Lamiaceae & Phlomis oreophila & Perennial & Invader & 1.7 & 1.7 \\
Plantaginaceae & Plantago lanceolata & Perennial & Increaser & 1.0 & 1.0 \\
Polygonaceae & Polygonum aviculare & Perennial & Invader & 0.3 & 0.3 \\
Ranunculaceae & Aconitum exelsum & Perennial & Invader & 1.0 & 1.0 \\
Rosaceae & Potentilla orientalis & Perennial & Invader & 0.3 & 0.3 \\
Rosaceae & Rosadumalis & Perennial & Invader & 0.3 & 0.3 \\
\hline Total & & & & $\mathbf{9 8 . 0}$ & $\mathbf{1 0 0 . 0}$ \\
\hline
\end{tabular}

24 species belonging to 22 genera of 10 families in Tokbay rangeland, 18 species belonging to 16 genera in 11 families in Alaarca rangeland, 21 species belonging to 20 genera of 9 families in Kaskasu rangeland, 19 species belonging to 17 genera of 9 families in Chungurchak rangeland, 23 species belonging to 22 genera of 13 families in Tatır rangeland were identified (Table 2, Table 3). It was determined that the number of species varied in the range of 19-24, while the highest number of species was in the Tokbay rangeland, and the lowest was in the Alaarca rangeland. The most common species in the rangelands were from the grasses (Poaceae) followed by legumes (Fabaceae) and chamomile (Asteraceae) (Table 2).

Table 3. Vegetation Characteristics of Rangelands Examined

\begin{tabular}{|c|c|c|c|c|c|c|c|}
\hline \multirow[b]{2}{*}{ Range } & \multirow{2}{*}{$\begin{array}{c}\text { Number of } \\
\text { Families }\end{array}$} & \multirow{2}{*}{$\begin{array}{c}\text { Number of } \\
\text { Genera }\end{array}$} & \multirow{2}{*}{$\begin{array}{c}\text { Number of } \\
\text { Species }\end{array}$} & \multirow{2}{*}{$\begin{array}{l}\text { Coverage } \\
\text { rate }(\%)\end{array}$} & \multicolumn{3}{|c|}{ Botanical Composition } \\
\hline & & & & & $\begin{array}{c}\text { Grasses } \\
(\%)\end{array}$ & $\begin{array}{c}\text { Legumes } \\
(\%)\end{array}$ & $\begin{array}{c}\text { Other Families } \\
(\%)\end{array}$ \\
\hline Tokbay & 10 & 22 & 24 & 97.0 & $41.2 b^{*}$ & $22.0 \mathrm{a}$ & $36.8 \mathrm{c}$ \\
\hline Kaskasu & 9 & 20 & 21 & 96.0 & $30.5 \mathrm{c}$ & $24.0 \mathrm{a}$ & $45.5 \mathrm{~b}$ \\
\hline Alaarca & 11 & 16 & 18 & 96.7 & $24.5 \mathrm{~d}$ & $11.7 \mathrm{c}$ & $63.8 \mathrm{a}$ \\
\hline Tatır & 13 & 22 & 23 & 98.0 & $33.3 \mathrm{c}$ & $4.7 \mathrm{~d}$ & $62.0 \mathrm{a}$ \\
\hline Chungurchak & 9 & 17 & 19 & 97.3 & $48.1 \mathrm{a}$ & $15.7 \mathrm{~b}$ & $36.2 \mathrm{c}$ \\
\hline Mean & 10.4 & 19.4 & 21.0 & 97.0 & 35.5 & 15.6 & 48.9 \\
\hline
\end{tabular}

* The mean values indicated by different letters in the same column are significantly different $(\mathrm{P} \leq 0.05)$ based on Duncan test

According to the life cycle, 15 species of Tokbay range were perennial and 9 of them were annual, 20 of species of Kaskasu range were perennial and one of them were annual, 16 species of Alaarca range were perennial and 2 of them were annual, all of 19 of species in Chungurchak range were perennial, and 21 of the species in the Tamir range were perennial and 2 were identified as annual species.

Depending on their responses to grazing, 3 of the species identified in Tokbay rangeland were decreaser, 1 was increaser, and 20 were invader. Among the species identified in Kaskasu rangeland 6 were decreaser, 3 were increaser, and 12 were invader. In Alaarca rangeland, 4 of the identified species were decreaser, one was increaser, and 
13 were invader. In Chungurchak rangeland, 6 of the species were decreaser, 2 were increaser, and 11 were invader. In Tatır rangeland, 5 were decreaser, 1 was increaser, and 17 were found to be invader species.

Medicago minima (20.3\%) in Tokbay rangeland, Dactylis glomerata (16.7\%) in Alaarca rangeland, Lolium perenne (15.7\%) in Kaskasu rangeland, Dactylis glomerata (23.7) in Tatır rangeland, and Dactylis glomerata (18.0\%) in Chungurchak rangeland were the species with high coverage rates (Table 2).

The number of species in similar studies conducted in natural rangelands was reported by Bakır (1970) as 82, by Erkun (1972) as 121, by Koc and Gokkus (1994) as 152, by Cinar (2001) as 77, by Sen (2010) as 111, by Inal et al. (2011) as 37, by Cinar et al. (2014) as 41, by Gur and Altin (2015) as 149-177, and by Cinar et al. (2019) reported as 8-22. The differences in the number of species among the reports can be explained by differences in grazing pressure (Bakir, 1970; Altin et al., 2011).

The ratio of plant-covered area for the rangelands investigated here were similar to the ones reported by Cinar et al. (2014) in Hatay Kirikhan and by Inal et al. (2011) Çukurova lowland rangelands. Nontheless, the values determined in this research are much higher than the ratio of plant coverage reported by Erkun (1971), Ozmen (1977), Tukel (1981), and Buyukburc (1983) in Central Anatolian rangelands, by Gokkus (1984), Koc and Gokkus (1994) in the Eastern Anatolian rangelands, and those reported by Seydosoglu et al. (2019) in Batman Kozluk. The discrepancy among results can be attributed to the difference between the vegetation measurement methods, as well as the difference between the soil, climate, precipitation, grazing pressure and grazing animals.

As seen in Table 3, the highest and lowest number of species were determined in Tokbay and Alaarca rangelands, respectively. Coverage ratios of the plants ranged from $96.0 \%$ to $98.0 \%$ in the rangelands examined and this variation among rangelands was not significant.

In the rangelands examined, the ratio of grasses in the plant covered area ranged between $24.5 \%$ and $48.1 \%$ and this difference was significant. It was determined that range with the highest rate of grasses $(48.1 \%)$ was Chungurchak and the lowest rate of grasses $(24.5 \%)$ was Alaarca. The rate of legumes ranged between 4.7-24.0\% and this variation was also significant. The rangeland with the highest legume composition (24.0\%) was Kaskasu and the lowest one $(4.7 \%)$ was the rangeland in Tatır. The ratio of other family species in the plant covered area ranged between $36.2-63.8 \%$ and was significantly different among rangelands. The rangeland with the highest percentage $(63.8 \%)$ of other family group was one in Alaarca. The finding that Poaceae were more abundant in the Chungurchak rangeland in comparison to the others may be explained by that it is farther away from settlement areas in comparison to the other rangelands and moderate grazed (Table 1, Table 3).

Total percentage of Geranium molle, Achillea millefolium, Taraxacum officinalis species in the botanical composition of the rangeland in Alaarca was calculated as $24.8 \%$ while the total percentage of Origanum vulgare, Geranium collinum, Achillea millefolium in botanical composition of the rangeland in Tatır was 35.9\%. Since the 3 species found in both rangelands were from other plant families, it can be concluded that the ratios of other plant families in Alaarca and Tamir were higher in the botanical composition compared to the covering area of other plant families. However, the reason for the high number of species in other plant families in these rangelands is the early and heavy grazing. 
In similar studies conducted in natural rangelands, the rate of grasses in the area covered with plants was determined by Erkun (1972) as $56.0 \%$, by Gokkus (1984) as $57.0 \%$, by Cinar et al. (2014) as $54.0 \%$, by Cinar et al. (2019) as 54.0\%, and by Seydosoglu et al. (2019) as $25.4 \%$. The rate of grasses determined in this research is lower than that of reported by Seydosoglu et al. (2019). This may be due to the different ecological conditions and grazing pressures of the rangelands.

In the previous research carried out in the rangelands, the rate of legumes in botanical composition was determined by Erkun (1972) as 8.0\%, by Gokkus (1984) as 7.8\%, by Uslu (2005) as $17.8 \%$, by Sen (2010) as $15.0 \%$, by Cinar et al. (2014) as $15.5 \%$, by Cinar et al. (2019) as $22.0 \%$, and by Seydosoglu et al. (2019) as $36.8 \%$. The composition of legume in this research was similar to the one in Sen (2010), Cinar et al. (2014), Cinar et al. (2019) but deviated from other studies. The differences among the rangelands could be attributed to the climate and grazing pressure differences.

The average rate of other family plants in botanical composition in the rangelands examined in the research is consistent with the findings of Erkun (1972) and Sen (2010), and deviates from the composition reported in Cinar (2001), Uslu (2005) and Cinar et al. (2014). It can be concluded that the differences in ecological conditions and grazing pressure between the rangelands contributed to the observed difference in botanicak composition.

It was determined that the majority of the species found in the rangelands with the exception of the rangeland in the Tokbay range were perennial (87.3-100.0\%), the number of annual species in the Tokbay rangeland and their percentage in the botanic composition are 9 and 49.4\%, respectively (Table 4).

Table 4. Number and percentage (\%) of species in each range based on the life span

\begin{tabular}{c|c|c|c|c}
\hline \multirow{2}{*}{ Range } & \multicolumn{2}{|c|}{ Annual } & \multicolumn{2}{c}{ Perennial } \\
\cline { 2 - 5 } & Number of Species & $\begin{array}{c}\text { Botanical Composition } \\
\text { Ratio (\%) }\end{array}$ & $\begin{array}{c}\text { Number of } \\
\text { Species }\end{array}$ & $\begin{array}{c}\text { Botanical Composition } \\
\text { Ratio(\%) }\end{array}$ \\
\hline Tokbay & 9 & 49.4 & 15 & 50.6 \\
Kaskasu & 1 & 0.3 & 20 & 99.7 \\
Alaarca & 2 & 12.7 & 16 & 87.3 \\
Tatır & 2 & 2.3 & 21 & 97.7 \\
Chungurchak & - & - & 19 & 100.0 \\
\hline
\end{tabular}

While the range of Tokbay is located immediately adjacent to a settlement, the distance of the rangelands other than the rangeland. The high number of annual species in Tokbay rangeland can be explained as heavy and uncontrolled grazing due to its close proximity to the settlement (Table 1).

Plant species in rangelands are classified according to their response to grazing as decreaser, increaser, and invader (Altin et al., 2011). The most sensitive to grazing and high-quality species are decreaser species and their rates in the rangelands examined were 29.4-51.0\%, having a lower quality compared to the decreaser species, the proportion of increaser species ranged from $1.0 \%$ to $15.7 \%$. With the withdrawing of decreaser and increaser species increases the proportion of the invader species, and they had a rate of 37.3- 69.6\% (Table 5). As the average of the five rangelands examined, the proportion of the decreaser species was $37.0 \%$, the proportion of increaser species was $7.3 \%$ and that of invader species was $55.7 \%$. The high amount of decreaser species in the Chungurchak rangeland where these were the most abundant may be explained by the it is grazed 
moderately due to its distance to settlement areas, while the low amount of these species in the Tokbay rangeland where these were the least abundant may be explained by that it is grazed heavily due to its proximity to settlement areas (Table 1). With heavy grazing, the decreaser species decrease and increaser species increase in a rangeland in time, and in the case of continuation of heavy grazing, the increaser species also decrease, but invader species increase (Bakir, 1987; Altin et al., 2011).

The high rate of invader species in the plant-covered area indicates that rangelands were grazed early, heavily, and over the capacity for many years, and were not utilized in accordance with proper grazing management (Altin et al., 2011).

Table 5. Botanical compositions of the rangelands based on the plant groups with different responses to grazing according to the degree of effect in the examined rangelands

\begin{tabular}{c|c|c|c}
\hline Range & Decreaser & Increaser & Invader \\
\hline Tokbay & 29.4 & 1.0 & 69.6 \\
Kaskasu & 40.5 & 15.7 & 43.8 \\
Alaarca & 32.7 & 2.0 & 65.3 \\
Tatır & 31.4 & 6.1 & 62.5 \\
Chungurchak & 51.0 & 11.7 & 37.3 \\
\hline Mean & 37.0 & 7.3 & 55.7 \\
\hline
\end{tabular}

The average coverage proportions of the decreaser and increaser species determined in the present research were higher than the proportions reported by Cinar et al. (2014) in the Kirikhan rangelands of Hatay, and those reported by Cinar et al. (2019) in the high plateaus of Adana; however, the proportions were lower than those reported by Gur and Altin (2015) in Tekirdag and by Seydosoglu et al. (2019) in Batman. Proportion of invader species were lower than those reported by Seydosoglu et al. (2019), and higher than those reported by Cinar et al. (2019) and Gur and Altin (2015). This difference might be due to the difference in the climate and grazing pressure (Gokkus, 1991).

The excess of invasive species is an indication that rangelands are not managed in accordance with the appropriate range utilization techniques (Holeckek et al., 2004). Decreaser species are the most delicious species preferred by animals in the first place. As a result of early and heavy grazing in the rangelands, initially decreaser species disappear from the rangelands, and if the grazing pressure continues, the increaser species withdraw from the environment and invader species occupy the rangeland vegetation area (Gokkus, 1991; Altin et al., 2011). In terms of animal nutrition, low quality annual grasses and legumes are classified as invader species (Gokkus, 1991). 58.1\% of the rangeland areas examined were covered with invasive species. This is an indication of early and heavy grazing (Cinar et al., 2019).

\section{Hay Yield and Forage Quality}

The data related to herbage yield and herbage quality in the rangelands examined in the current research are listed in Table 6.

As shown in Table 6, DMY varied between 2053.0 and $3690.0 \mathrm{~kg} \mathrm{ha}^{-1}$, CPY between 221.7 and $417.0 \mathrm{~kg} \mathrm{ha}^{-1}$, DDMY between 118.7 and $216.2 \mathrm{~kg} \mathrm{ha}^{-1}$, RFV between 94.5 and 96.7. Differences among rangelands in DMY and DDMY were statistically significant. The highest DMY, CPY and DDMY were found in Chungurchak rangeland, the lowest DMY, CPY, and DDMY were determined in Tokbay rangeland. 
The highest yield in the Chungurcak rangeland is the distance of this its to the settlement, grazing density, and the decreasing species are higher than other pastures. In Tokbay pasture, it can be explained as low yield, close to settlement, heavy grazing and very low rate of reducing species (Table 1, Table 5). DDMY was generally calculated as high in pastures with high yields. This is an expected result.

Among the various studies carried out in rangelands, Sen (2010) reported DMY of $850-1720 \mathrm{~kg} \mathrm{ha}^{-1}$, the proportion of CP of $17.2 \%$, CPY of $230 \mathrm{~kg} \mathrm{ha}^{-1}$. Cinar et al. (2015) reported DMY of $830 \mathrm{~kg} \mathrm{ha}^{-1}$, CP of $11.0 \%$, of CPY of $90 \mathrm{~kg} \mathrm{ha}^{-1}$, ADF composition of $33.4 \%$, NDF composition of 49.4\%, and DDMY of $630 \mathrm{~kg} \mathrm{ha}^{-1}$. DMY was reported by Cacan and Basbag (2016) as $1440 \mathrm{~kg} \mathrm{ha}^{-1}$ and by Seydosoglu et al. (2019) as $2980 \mathrm{~kg}$ $\mathrm{ha}^{-1}$. Ozaslan Parlak et al. (2015) reported DMY as 900-3330 kg ha-1, the proportion of $\mathrm{CP}$ as $11.0 \%$, ADF composition as $30.2 \%$, and NDF composition as $47.5 \%$. Polat et al. (2018) noted the DMY as $1840 \mathrm{~kg} \mathrm{ha}^{-1}$, CP content as $7.5 \%, \mathrm{CPY}$ as $130 \mathrm{~kg} \mathrm{ha}^{-1}$. Surmen and Kara (2018) estimated the DMY as 1630, CP content as $6.1 \%$, CPY as $150 \mathrm{~kg} \mathrm{ha}^{-1}$, ADF composition as $39.5 \%$, NDF composition as $60.3 \%$, and the RFV as 91.4. According to the results obtained from the current research, DMY was similar to the value reported by Ozaslan Parlak et al. (2015), the rate of CP was closer to Cinar et al. (2015), and ADF and NDF composition values were in agreement with Surmen and Kara (2018). Ozaslan Parlak et al. (2015) stated that CP content above 7.5\% is acceptable for livestock. In general, it can be concluded that DMY, CPY, and DDMY increased as the altitude increased. There was no coherence with the aforementioned studies in terms of other investigated variables. The reason for this may be the difference in the ratio of species found in the botanical composition in rangelands, climatic conditions, soil variables, precipitation patterns, and grazing pressures.

Table 6. DMY, CP, ADF, NDF, CPY, DDMY and RFV in investigated rangelands

\begin{tabular}{|c|c|c|c|c|c|c|c|}
\hline Range & $\begin{array}{c}\text { DMY } \\
\left(\mathrm{kg} \mathrm{ha}^{-1}\right)\end{array}$ & $\begin{array}{l}\mathrm{CP} \\
(\%)\end{array}$ & $\begin{array}{c}\text { ADF } \\
(\%)\end{array}$ & $\begin{array}{l}\text { NDF } \\
(\%)\end{array}$ & $\begin{array}{c}\mathrm{CPY} \\
\left(\mathrm{kg} \mathrm{ha}^{-1}\right)\end{array}$ & $\begin{array}{c}\text { DDMY } \\
\left(\mathrm{kg} \mathrm{ha}^{-1}\right)\end{array}$ & RFV \\
\hline Tokbay & $2053.0 c^{*}$ & 10.8 & 39.9 & 56.3 & $221.7 \mathrm{c}$ & $1187.0 \mathrm{~d}$ & 95.5 \\
\hline Kaskasu & $2354.0 \mathrm{c}$ & 10.4 & 39.4 & 56.4 & $244.8 \mathrm{c}$ & $1370.0 \mathrm{c}$ & 96.7 \\
\hline Alaarca & $2995.0 \mathrm{~b}$ & 10.2 & 38.9 & 57.7 & $305.5 \mathrm{~b}$ & $1755.5 \mathrm{~b}$ & 94.5 \\
\hline Tatır & $3431.0 \mathrm{ab}$ & 10.2 & 38.5 & 57.9 & $350.0 \mathrm{a}$ & $2021.0 \mathrm{a}$ & 94.6 \\
\hline Chungurchak & $3690.0 \mathrm{a}$ & 11.3 & 38.9 & 57.2 & $417.0 \mathrm{a}$ & $2162.0 \mathrm{a}$ & 95.3 \\
\hline Mean & 2904.6 & 10.6 & 39.1 & 57.1 & 307.8 & 1699.1 & 95.3 \\
\hline
\end{tabular}

${ }^{*}$ The mean values indicated by different letters in the same column are significantly different $(\mathrm{P} \leq 0.05)$ based on Duncan test

\section{Range Condition}

The range quality scores calculated using botanical composition ratios and quality scores of plant species found in each rangeland ranged from 3.6 to 5.1. Chungurchak rangeland was found to be moderate and other rangelands were classified as poor. quality scores and range condition of the five rangelands examined are shown in Table 7.

The low range quality in the examined rangelands might can be attributed to disappearance of high-quality species due to uncontrolled, early, and heavy grazing for many years that have led spread of lower quality species (Koc, 1995; Cinar et al., 2014). Similarly, range statue ranged between very poor and poor were reported in Kilis rangelands (Sen, 2010), in the Kirıkhan rangelands of Hatay (Cinar et al., 2014), and in the higher parts of Adana (Cinar et al., 2019). 
Table 7. Quality scores and range condition of the five rangelands examined

\begin{tabular}{c|c|c}
\hline Range & Range Quality Score & Range Status \\
\hline Tokbay & 3.6 & Poor \\
Kaskasu & 4.6 & Poor \\
Alaarca & 4.5 & Poor \\
Tatır & 4.0 & Poor \\
Chungurchak & 5.1 & Moderate \\
\hline
\end{tabular}

\section{Conclusions}

This research was carried out in order to determine the hay yield, forage quality, botanical composition and range condition in different natural rangelands (Tokbay, Kaskasu, Alaarca, Tatır, Chungurchak) located in different altitudes in Chuy Region, Kyrgyzstan. In the vegetation research, average of 21 species belonging to 19.4 genera from 10.4 families were identified. In these rangelands, the ratio of plant coverage was $96.0-98.0 \%$, the ratio of grasses in the plant covered area was $24.5-48.1 \%$, the proportion of legumes was $4.7-22.0 \%$, and the proportion of other family plants ranged from $36.2-63.8 \%$. In the rangelands, the rate of decreaser species was $37.0 \%$, the rate of increaser species was $7.3 \%$ and the rate of invader species was $55.7 \%$. The average dry matter yield of range was $2904.6 \mathrm{~kg} \mathrm{ha}^{-1}$, crude protein was $10.6 \%$, ADF and NDF compositions were $39.1 \%, 57.1 \%$, respectively. The crude protein yield was $307.8 \mathrm{~kg} \mathrm{ha}^{-}$ ${ }^{1}$, digestible dry matter yield was $1699.1 \mathrm{~kg} \mathrm{ha}^{-1}$, and relative feed value was 95.3 .

We can say that rangelands are different in aspect, slope, distance to settlement and grazing pressure.

It has been determined that approximately half of the rangelands are other family species, more than half are perennial species, and more than half are invasive species. We can say that the grazing pressure decreases as the pastures move away from the settlement area, the yield increases as the altitude rises, and grazing without control. One of the rangelands was in the moderate condition and the others were in poor range condition.

In the rangelands investigation and in similar ecological conditions, it is necessary that increase hay yield and forage quality to regulate grazing, minimize invasive species and weed rate and increase the decreasing species.

For this purpose, investigated rangelands and with similar ecological contiditons is recommended to make and implement new projects for pasture control, fertilization, overseeding and grazing.

Acknowledgements. The research is part of the project BAP-2018.FBE.07 supported by Kyrgyz-Turk Manas University. We thank Kyrgyz-Turk Manas University for supporting the project.

\section{REFERENCES}

[1] Altin, M., Gokkus, A., Koc, A. (2011): Meadow Range Management, 2nd volume. Ministry of Agriculture and Rural Affairs TUGEM Publications, Ankara-Turkey.

[2] ANKOM (2009): Method for determining acid detergent fiber and neutral detergent fiber. - Ankom Technology, www.ankom.com, Access on 15 August 2009.

[3] Anonymous (1962): Range Research: Basic problems and techniques. - National Academy of Science. National Research Council Pub. 
[4] Anonymous (1995): The Determination Of Nitrogen According To Kjeldahl Using Block Digestion And Steam Distilation. - Tecator Application Note An 300, Tecator Ab Sweden: $1-11$.

[5] Anonymous (2005): Guide to Range Crops. - Ministry of Agriculture and Rural Affairs General Directorate of Agricultural Production and Development, Ankara-Turkey.

[6] Anonymous (2008): Guide to Range Crops. - Ministry of Agriculture and Rural Affairs General Directorate of Agricultural Production and Development, Ankara-Turkey.

[7] Anonymous (2015): Kyrgyzstan Pasture Plants Catalog, Flermoneca.

[8] Anonymous (2019): https://tr.climate-data.org/asya/k\%C4\%B1rg\%C4\%B1zistan/chuiprovince/biskek-484/\#climate-graph (02.05.2019).

[9] Bakır, O. (1970): A Pasture Study on the Land of Middle East Technical University. - AU Faculty of Agriculture Publications: 232, Ankara-Turkey.

[10] Bakır, O. (1987): Meadow-Range Management. - Ankara University Faculty of Agriculture Publications: 992, Ankara-Turkey.

[11] Blanchet, K., Moechnig, H., DeJong-Hughes, J. (2003): Grazing systems planning guide. - University of Minnesota Extension Service, BU-07606-S, http://www.extension. umn.edu/agriculture/beef/components/docs/grazingsystemsplanning.guide.pdf (01.11.2018).

[12] Blench, R., Sommer, F. (1999): Understanding Rangeland Biodiversity. - In: Working Paper 121. Overseas Development Institue. London: Chameleon Press, 51.

[13] Buyukburc, U. (1983): A Research on the Possibilities of Breeding the Pastures of Yavrucak Village in Ankara by Fertilizing and Resting. - Meadow-Range-Animal Science Research Institute Publications No: 79, Ankara.

[14] Cacan, E., Basbag, M. (2016): Change of Botanic Composition and Herb Yields in Pasture Sections of Yelesen-Dikme Villages in Bingöl Province in Different Directories and Elevations. - Journal of Ege Univ. Faculty of Agriculture 53(1): 1-9.

[15] Cinar, S. (2001): A Research on Determination of Yield and Botanical Composition in Hanyeri Village Pasture in Tufanbeyli District of Adana Province. - C.U. Graduate School of Natural and Applied Sciences, Field Crops Department Master Thesis, 70 p. Adana.

[16] Cinar, S., Hatipoglu, R., Avci, M., Yucel, C., Inal, I., Avag, A. (2014): Hatay Province Kirıkhan District a Research on Vegetation Structure of Base Pastures. - Gaziosmanpasa U. Journal of Faculty of Agriculture JAFAG 31(2): 52-60.

[17] Cinar, S., Hatipoglu, R., Avci, M. (2015): Effects of Some Weed Control Methods on Herb Yield, Botanical Composition and Weed Quality in the Pastures of Mediterranean Region. - Journal of Agricultural Sciences 21(1): 39-49.

[18] Cinar, S., Hatipoğlu, R., Avci, M., Yucel, C., Inal, I. (2019): A Research on Vegetation Structure of Pastures in Tufanbeyli District of Adana Province. - KSU J. Agric Nat 22(1): 143-152.

[19] Davis, P. H. (1970): Flora of Turkey and the East Aegean Islands. - University of Edinburgh Press, Volume 1-3, Edinburgh.

[20] Demiri, M. (1983): Flora Ekskursionistee Shqiperise T, Shtepia Botuesee Librit Shkollor Tirane.

[21] Eddy, I. (2016): Land degradation in Central Asia. - The Faculty of Graduate and Postdoctoral Studies Master of Science, The University of British Columbia.

[22] Edgecombe, W. (1964): Weeds of Lebanon. - Faculty of Agriculture Sciences, American University of Beirut, Lebanon, Publication No: 24.

[23] Erkun, V. (1971): Pasture Surveys in Hakkari and Van Provinces. - Ministry of Agriculture General Directorate of Agriculture Affairs Publications, G.13, Ankara. (In Turkish).

[24] Erkun, V. (1972): Research on Pastures of Bala District. - Ministry of Agriculture Livestock Development Publications, Ankara.

[25] Garms, H., Eigener, W., Melderis, A., Pope, T., Durrell, G. (1968): The Natural History of Europe. - Paol Hamilyn Limited, London. 
[26] Gokkus, A. (1984): Investigation on Herbal and Crude Protein Yields and Botanical Composition of Erzurum Natural Pastures Applied to Different Breeding Methods. - A.Ü Institute of Science and Technology, Doctorate Thesis, Field Crops Department, 145p. Erzurum.

[27] Gokkus, A. (1991): Training Seminar on Meadow Pasture and Forage Crops and Livestock Development Project in Eastern and Southeastern Anatolia Regions. - February 20-22, 1991, Erzurum.

[28] Gokkus, A., Koc, A., Comakli, B. (2000): Meadow Pasture Application Guide. Extended 3rd Edition. - Atatürk University Faculty of Agriculture Publications No: 142. (In Turkish).

[29] Gur, M., Altin, M. (2015): Some properties of fluorastic compositions of pastures with different usage history in Trakya region. - Journal of Anatolian Agricultural Sciences 30: 60-67.

[30] Holeckek, J. L., Pieper, R. D., Herbel, C. H. (2004): Range management: Principles and practicies. - Prentice Hall, New Jersey 607p.

[31] Huxley, A., Taylor, W. (1977): Flowers of Greece and the Aegean. - Chatto and Windus Ltd. Printed Great Britain by Richard Clay Ltd Bunges, Suffolk.

[32] Inal, I., Avci, M., Cinar, S., Yucel, C., Hatipoglu, R. (2011): A Research on Vegetation Structure of Coast Pastures. - IX. Field Crops Congress Presentation 3: 1664-1667. September 12-15 Bursa.

[33] Koc, A., Gokkus, A. (1994): Determination of the optimum stubble height to be left by the botanical composition and soil covering area of the pasture vegetation in Güzelyurt. Turkish Journal of Agriculture and Forestry 18(6): 498-500.

[34] Koc, A. (1995): Topography and soil moisture and temperature effects on some properties of pasture vegetation. - Atatürk Univ. Graduate School of Natural and Applied Sciences, Field Crops Department, 177p. Erzurum.

[35] Koc, A., Cakal, S. (2004): Comparison of some rangeland canopy coverage methods. - Int. Soil Cong. On Natural Resource Manage, for Sust. Develop., June 7-10, 2004, Erzurum, Turkey, D7, pp. 41-45.

[36] Mirzabaev, A., Ahmed, M., Werner, J., Pender, J., Louhaichi, M. (2016): Rangelands of Central Asia: Challenges and Opportunities. - J. Arid Land 8(1): 93-108.

[37] Nishanov, N. (2015): Sustainable livestock management under changing climate in Central Asia. - $\quad$ https://www.iamo.de/fileadmin/user_upload/Bilder_und_Dokumente/06veranstaltungen/recca/C1_2_Nariman_Nishanov.pdf (16.01.2018).

[38] Ozaslan Parlak, A., Parlak, M., Gokkus, A., Demiray, H. C. (2015): Herb Yield and Quality, Botanical Composition and Some Soil Properties of Mediterranean Pastures. COMU J. Agric. Fac. 2(1): 99-108.

[39] Ozmen, T. (1977): Research on the vegetation of the pastures of Konya. - Ankara Univ. Graduate School of Natural and Applied Sciences Field Crops Department, Ph.D. 126p. Ankara.

[40] Oztan, Y., Okatan, A. (1985): Introduction to pasture legumes and forage crops. Volume II. - K.Ü. Faculty of Forestry. Karadeniz University Press Publication No: 95, Faculty Publication No: 8, Trabzon.

[41] Polat, T., Buyukhatipoglu, S., Akkaya, G. (2018): Determination of Plant Composition, Herb Yield and Quality of Pastures in Different Directories in the Individual Mountains of Sanliurfa. - Harran Journal of Agriculture and Food 22(2): 248-254.

[42] Polunin, O., Huxley, A. (1974): Flowers of the Mediterranean. - Chatto and Windus, London.

[43] Rosales, M., Livinets, S. (2017): Grazing and Land Degradation in C1s Countries and Mongolia. - http://www.fao.org/fileadmin/templates/lead/pdf/e-conf_05-06_background. pdf (18.01.2018).

[44] Sen, C. (2010): A Research on the Vegetation Structure in Pastures in Some Villages of Kilis Province. - Master Thesis. Cukurova University Graduate School of Natural and Applied Sciences Field Crops, Adana. (In Turkish). 
[45] Seydosoglu, S., Cacan, E., Sevilmis, U. (2019): Determination of Botanical composition, yield and range quality ratings of intertile rangelands in Kozluk district of Batman province of Turkey. - Fresenius Environmental Bulletin 28(4A): 3388-3394.

[46] Sheaffer, C. C., Peterson, M. A., Mccalin, M., Volene, J. J., Cherney, J. H., Johnson, K. D., Woodward, W. T., Viands, D. R. (1995): Acid detergent fiber, neutral detergent fiber concentration and relative feed value. - North American Alfalfa Improvement Conference, Minneapolis.

[47] Steel, R. G. D., Torrie, J. H. (1960): Principles and Procedures of Statistics with Special Reference to the Biological Sciences. - Mc Graw-Hill Book Co., Inc., London.

[48] Surmen, M., Kara, E. (2018): Yield and Quality Characteristics of Pasture Vegetations on Different Slopes in Aydın Province Ecological Conditions. - Derim 35(1): 67-72.

[49] Tekindal, B. (1998): Prerequisites and Analysis of Variance Analysis. - A.Ü Ziraat Fak. Graduate School of Natural and Applied Sciences, Department of Animal Science PhD thesis, 70p.

[50] Tukel, T. (1981): Investigations on Determination of Vegetation and Yield Strengths of Meadows that are Common to a Typical Steppe Mountain Preserved in Ulukisla. Associate Professor Thesis. Cukurova University Faculty of Agriculture, Adana. (In Turkish).

[51] Uslu, O. S. (2005): Research on the Determination of Botanic Composition in Yeniyapan Pasture in Araplar Village of Turkoglu District of Kahramanmaras Province and Effects of Different Fertilizer Applications on Yield and Botanic Composition of Pasture. - Ç.Ü. Graduate School of Natural and Applied Sciences Field Crops Ph.D. Thesis, 162p., Adana.

[52] Uzun, F., Alay, F., Ispirli, K. (2016): Some characteristics of the pastures of Bartın province. - Turkey Agricultural Research Journal 3(2): 174-183.

[53] Weymer, H. (1981): Lernt Pflanze Kennen. - Ferdinand Enke Verlag, Stuttgart.

[54] Yurtsever, N. (1984): Experimental Statistical Methods. - General Directorate of Rural Services Publications No: 121, Ankara. 